\title{
The Study of the Effects of Educational Judo Practices on Motor Abilities of 7-12 Years Aged Judo Performing Children
}

\author{
Şengül Demiral, PhD. \\ High Performance Planning Coordinator of Turkish Judo Federation \\ Education Committee Member of Turkish Judo Federation \\ \& Junior Women's National Team Coach of Turkish Judo Federation- Edirne, Turkey \\ E-mail: judo_edirne22@hotmail.com
}

Received: March 7, 2011 Accepted: May 2, $2011 \quad$ doi:10.5539/ass.v7n9p212

\begin{abstract}
In this study, the impacts of educational judo practices on motor abilities of judo performing 7-12 years aged children have been studied. Experimental and control groups have been started with $n=40$ judoka number for the study. and the study has been completed with $n=38$ judoka number for the experimental gruop and $n=31$ judoka (Note 1) number for the control groups. This study was run during the twelve months. At the begining and end of this work, anthropometric measures of the experimental group and control group and application of static and dinamic balances, coordinations, celerities, long jumping, ball launching, claw-back forces, speed tests have been applied and pre-test and re-test results have been taken. After the reorder and grouping of mesaurement parameters and introduction forms, all the data has been scoped out on SPSS for Windows (ver. 14). Arithmetic average and standard deviation of parameters have been analyzed. According to the data acquired from the research comparison between pre-test and re-test of the experimental gruop, comparison between pre-test and re-test of the control group, comparison between the pre-tests of the experimental and control groups, comparison between the re-tests of the experimental and control groups, comparison between the pre-tests of the experimental and control groups and one-sided variant analysis of re-tests of the experimental and control groups have been realized. Between the parameters of Test and Control groups, $p<0.05$ and $p<0.01$ level differences are tried to be detected. Finally, male judokas of the experimental group's static balance, celerity, claw force and back power parameters has been found different at $p<0.05$ level and quite at $p<0.01$ quite different when compared to control group and these educational Judo games are highly contributive to the development motor skills. Female judokas of the experimental group's static balance, celerity, claw force and back power parameters has been found different at $p<0.05$ level and quite at $p<0.01$ quite different when compared to control group and these educational Judo games are highly contributive to the development motor skills. As a result of this study we can say that static and dynamic balance, quickness, hand grip and back strength, coordination, speed parameters of the male and female judokas' have developed. Considering these parameters usage of Judo educational games, which are accelerating the development of basic motor skills of 7-12 years aged children,in courses by arrangement can be suggested.
\end{abstract}

Keywords: Balance, Coordination, Educational game, Judo, Skill

\section{Introduction}

The game is the most direct, easiest, most meaningful way in which the child is able to express himself. Child provides his physical, cognitive, sensory and social development by game. Shortly the game is a life-learning tool for children and all living organisms. But learning is long-term permanent change which emerges due to the behavior and knowledge individual has had in life. This changes occurs as a result to the experiences the individual has had (Ataman 2004, s.18).

The game is an event which affects all the positive development of the child ( psycho-motor, emotional, social, cognitive and language) that perform their imagination, refers the child to creativity and also gives the child the joy and excitement. Game which remains valid for people of all ages, is an indispensable amusement source for children. With a nice amusement environment the development of speech, motor, cognitive and social skills of the children increases unconsciously. The game which has a major role in a normal child's life also has such a major importance in a handicapped child's education (Bayazit 2006, s.78-80). 
Studies in the field of child development not only inform about the development condition and direction but also represent scientific informations about how and what will be taught. Movement is one of the most important factors that contribute to child development. Children love moving. Movement is a part of the child's life from the beginning of the birth. Children feel excitement and happiness while while movement.So there are so many reasons to support the children's movement oppurtunities. It is declared that real learning and growth occurs at the time of movement (Hu1-Tzu 2003, s.1).

One of the forms in which movement education training performed is Sport. Sport is a tool that provides the phsycal, mental, emotional and social development and improves intelligence, skill and leadership skills of the child. Major objective of the child's sport should be to raise cardiovascular endurance and to develop neuromuscular coordination, power and flexibility. These features can be entitled to the pre-school and primary education children in the form of game by pedagogical approachment (Mengütay 2006, s.114).

One of the sports that children's cognitive, sensitive and motor development gained is "Judo". Judo sutains the characteristic features of desert civilization as a Central Asia origined combat and mental system. Bowdlerized from weapon and brute, this sport is a combat art which is predicated on functional intelligence, rapid succession, discern as mental and phsycally reflection of all the body power to the target point (Brousse and Matsumoto, 1999, s.7-10)

Judo is a great branch of combat sport which requires great mental and phsycal skill. As a literal meaning of word; Judo means; JU: softness, flexibility, gentility, delicacy, agility. DO:method,principle, thinking (Demiral 2007, s. 14-15).

Judo is a sport that requires high-level skill. Development of the analytic functions quick perception and movement quality are the specific features that are expected from the athletes. In addition, the decisions in the case of a complex play of the athletes depends on their sensing external stimuli characteristics. Levels of Quick thinking and interpreting are the factors that helps the athlete to prevent the opponent to make a succesfull tactical behavior or help his team to behave succesfully (Bompa 2007, s.14-294).

When the above analysis are identified judo is taught to contribute physical, mental, emotional, cognitive development to the children's movement development. So appropriate training programs in judo is thought to accelerate the development of child who is at the age-sensitive circuits to which the most positive and lasting contributions can be done. Hence, in this study to investigate the effect of educational judo practices on motor abilities of 7-12 years aged judo performing children is aimed.

\section{Materials and Methods}

80 judokas (male and female) were included in the study who recieve judo training at the Edirne and Tekirdağ Provincial Directorate of Youth and Sports. The study has began with 80 judoka which is apllication team $n=40$ (Edirne judo team) and control team $n=40$ (Tekirdağ judo team) $n=40$ ve control grup (Tekirdağ judo takımı). During the 12 month study period 2 judokas from the application team and 9 judokas from the control team who do not meet the criteria of the study has been removed from the group. So the study has been completed with 38 judokas from application team and 31 judokas from control team. Preliminary test and last test parameters has been detected for static balance, dynamic balance, speed, quickness, ball throw, standing long jump, coordination, claw, back and leg strength tests.

\subsection{Motor Test Measurements}

- Dynamic Balance Test

Aim: Child's number of jumping on one leg for each left and right leg is recorded in an area of $100 \mathrm{~cm}^{2}$.

Application: It is told to the child who was taken to the exercises room that some movement will be taught so that he should watch his friend carefully. When Model, the child's hand and foot touches the ground the motion is repeated.Movement is recorded for left and right leg. Rewievs: Jumping number is recorded for left and right leg when the child removed his foot. Best performance is get from the two application of the child (Özer and Özer 2000, s.187).

\section{- Flamingo Static Balance Test (Balance on One Foot Stop)}

Aim:To determine the period child's on foot stop time. Vehicle: stopwatch. Application: It is told to the child who was taken to the exercises room that some movement will be taught so that he should watch his friend carefully. Stopwatch is introduced and to show the movement is wanted from the model. Model child slippes out and when when lifting his foot with the "lift" direction, the movement is defined by the researcher .He makes a statement: "Your friend is trying to balance on one foot as long as possible and the stopwatch shows me the balancing time." 
After the model showed the movement the child is wanted to make the same movement, He say "Try to balance on your one foot, whichever you want,like your friend has showed ." And the oppurtunity is given the child to try with the "lift" direction. He is allowed to rest after two application. When a problem occurs due to the stopwatch, application is repeated. Rewievs: Stopwatch is run when the child lift his leg and stopped when he touched the ground with his hand or foot. Best performance is get from two application (Özer and Özer, 2000, s.180).

- Coordination Test ( Balance Skill)

Aim: To determine the child's coordination. Vehicle: Stopwatch,colored tape, 6 tower, 2 obstacle.

Application:The kid Getting out of the output line;

1). station: half jump (hands down,legs open shoulder width in a strained position, opening-closing and jump up) is done

2). Jumps from the $50 \mathrm{~cm}$ height (double or single leg) by running,

3). pass from the bottom of the $50 \mathrm{~cm}$ height obstacle by running,

4). Walks fastly from the $5 \mathrm{~cm}$ thick tape,

5). Do slalom between towers,

6). Finishes the test by sprint untill the finishing line.

Rewiev: Best performance is get from the two applications (K1z1lyaprak 2008).

- Rapidity Test

Aim: To measure the time between the child lying on his back stand up run $3 \mathrm{mt}$ get the tenis ball and llie down again. Gives information about the child's attention span and coordination. Preparation of the test environment: 1 $\mathrm{mt}$ long colored tapes are pasted in paralel with a distance of 3 meter. Tenis ball is placed to one tape and the other is used fort he child. Vehicles: Stopwatch, colored tapet, tennis ball,chalk.

Application: It is told to the child who was taken to the exercises room that some movement will be taught so that he should watch his friend carefully. Model child lyes down through the ball he runs to the ball when he get the directive "ready,go" gets the ball and turns back and lyes down again. The movement is explained and the rapidity of the movement attracts attention. The child is helped to lie down through the line (legs off,arms adjacent to the body). The movement wanted to be done as quick as possible and directions are given to the child. Two application is done after a trial opportunity. The child is allowed to rest between applications. The application is repeated when the child can not achieve the movement, fall down, fall the ball or begin the movement before the direction Rewiev: Stopwatch is run with the "Begin" directive, and stopped after he get the tennis ball. Best performance is get from the two applications (Özer and Özer, 2000, s.181).

\section{- Standing Long Jump Test}

Aim:To measure how far the child can jump By moving the body forward. And also gives information about the two-way co-ordination of the body. Preparation of the test environment: Colored tape is stuck to the floor to determine the boundary line. Vehicles: 1 tape measure, 2 tape. Application: It is told to the child who was taken to the exercises room that some movement will be taught so that he should watch his friend carefully.. Later the child is helped to, open his legs at shoulder width and to take the position not to exceed the tape. He is directed to Bend his knees, wave his arms backwards by jumping. And he is wanted to jump as far as possible and stay stil with the "jump" direction. Two apllication is done after a trial opportunity is given to the child. The application is repeated if the child falls down or pass the boundary line. Rewiev: The distance between boundary line and and heel of the foot is measured.Best performance is get from the two applications (Özer and Özer, 2000, s.166).

\section{- Ball Throw Test}

Aim:To measure how far he can throw the medicine ball with his both hands with the position his legs at the shoulder width. It gives information about the upper region power of the child. Preparation of the test environment: Colored tape is stuck to the floor to determine the boundary line. Vehicles: 1 tape measure, 1 tape, $2 \mathrm{~kg}$ medicine ball. Application: It is told to the child who was taken to the exercises room that some movement will be taught so that he should watch his friend carefully. And than he is helped to throw the ball by getting position his legs open shoulder width. He is directed to bend his knees and use his upper region. He is wanted to throw the ball as far as possible. Two apllication is done after a trial opportunity is given to the child. The application is repeated to the child if he passes the boundary line. Rewiev: The distance between the boundary line and the point where the ball fall is measured as cm.Best performance is get from two applications (GSM - SEDB, 2005, s.61). 


\section{- $\quad$ Speed Test (Running test)}

Aim: To determine how quick the child run $12.2 \mathrm{~m}$ distance. Preparation of the test environment: Start line is determined after tape is glued $(3.65 \mathrm{~m}$ distance for acceleration site, $12.2 \mathrm{~m}$ distance to evaluate running time,and $3.65 \mathrm{~m}$ distance for both cutting the speed and for start line fort he second application). So when the child comes to finish line he will be also at the start line. This will prevent time and energy loss.Block is placed to the start and finish line. Vehicle: Stopwatch, 4 one meter distance colored tape, 2 block. Application: It is told to the child who was taken to the exercises room that some movement will be taught so that he should watch his friend carefully.The child watches the model and attracts attention how quick he runs and touches the block.Than he is clearly explained what to do.He runs as soon as possible when he hears the "begin" direction and touches the block. Stopwatch shows how quick he reaches to the block.The child is provided to do 3 applications by "ready,go" directive. He is allowed to rest between applications. The application is repeated if the child passes the line,falls down,loose attention or a problem occured. Rewiev: Stopwatch is run when he passes the second tape and stopped when he passes the third tape.The best performance is get from two applications (Özer and Özer, 2000, s.186).

\section{- $\quad$ Grip and Back Power}

Test Aim: The child takes position in front of the pull-up,hangs up from both the sides of the judogi which is hanged to the pull-up.The aim is to measure the time.It gives information about the grip and back power of the child. Preparation of the test environment: Pull-up prepared in a wide range. Vehicles: 1 stopwatch, pull-up, uvagi. Application: It is told to the child who was taken to the exercises room that some movement will be taught so that he should watch his friend carefully.And than the child is helped to take position by opening his legs shoulder width. He is wanted to hang uvagi which is hanged to the pull-up. Application is done after a trial. Rewiev: The time is measured when he leaves the pull-up.Best performance is get from two applications (Kizilyaprak 2008).

\section{Results}

\subsection{Motor Test Measurements}

When comparisons of the pre last test results of male judokas' of the application group determined; static balance test $(\mathrm{F}=7.230)$; pre-test 01:27.68 $\pm 01: 23.21 \mathrm{~min} . \mathrm{sc}, \mathrm{ss}$, last-test 03:14.79 $\pm 02: 27.09 \mathrm{~min} . \mathrm{sc}, \mathrm{ss}$, rapidity test $(\mathrm{F}=13.222)$; pre-test $4.83 \pm 0.49 \mathrm{sc}, \mathrm{ss}$, last-test $4.22 \pm 0.53 \mathrm{sc}, \mathrm{ss}$, grip power $(\mathrm{F}=10.689)$; pre-test $71.98 \pm 34.77 \mathrm{sc}, \mathrm{ss}$, last-test $110.90 \pm 36.64 \mathrm{sc}, \mathrm{ss}$, speed test $(\mathrm{F}=16.637)$, pre-test $2.48 \pm 0.16 \mathrm{sc}$,ss, last-test $2.25 \pm 0.17 \mathrm{sc}$,ss, parameters levels has shown differences. $\mathrm{p}<0.05$ (Table 1). When comparisons of the pre -last test results of male judokas' of the Edirne application group determined; standing long jump ( $\mathrm{F}=8.976)$; pre-test $147.33 \pm 15.44 \mathrm{~cm}$, last-test $164.00 \pm 17.85 \mathrm{~cm}$, ball throw $(\mathrm{F}=4.541)$; pre-test $377.33 \pm 73.76 \mathrm{~cm}$, last-test $438.50 \pm 96.90 \mathrm{~cm}$, coordination $(\mathrm{F}=7.392)$; pre-test $15.60 \pm 2.23 \mathrm{sc}, \mathrm{ss}$, last-test $13.90 \pm 1.45 \mathrm{sc}, \mathrm{ss}$, Very significiant differences has been found at the parameter levels $\mathrm{p}<0.01$ (Table 1).

When comparisons of the pre -last test results of female judokas' of application group determined; static balance test $(\mathrm{F}=10.681)$; pre-test 02:42.01 $\pm 02: 21.490 \mathrm{~min} . \mathrm{sc}, \mathrm{ss}$, last-test 05:57.92 $\pm 03: 47.703 \mathrm{~min} . \mathrm{sc}, \mathrm{ss}$, rapidity test $(\mathrm{F}=40.468)$; pre-test $4.89 \pm 0.42 \mathrm{sc}, \mathrm{ss}$, last-test $3.97 \pm 0.49 \mathrm{sc}, \mathrm{ss}$, standing long jump ( $\mathrm{F}=9.573)$; pre-test $146.50 \pm 19.00 \mathrm{~cm}$, last-test $165.10 \pm 19.02 \mathrm{~cm}$, coordination $(\mathrm{F}=12.608)$; pre-test $16.38 \pm 1.14 \mathrm{sc}, \mathrm{ss}$, last-test $14.17 \pm 2.53 \mathrm{sc}, \mathrm{ss}$, grip power $(\mathrm{F}=18.049)$; pre-test $68.05 \pm 30.84 \mathrm{sc}, \mathrm{ss}$, last-test $113.02 \pm 35.91 \mathrm{sc}, \mathrm{ss}$, speed test $(\mathrm{F}=26.246)$, pre-test $2.54 \pm 0.19 \mathrm{sc}, \mathrm{ss}$, last-test $2.24 \pm 0.19 \mathrm{sc}, \mathrm{ss}, \mathrm{p}<0.01$ very significiant differences has been found at the parameter levels (Table 2).

When comparisons of the pre -last test results of male judokas' of the control group determined; standing long jump ( $\mathrm{F}=20.389)$; pre-test $138,53 \pm 21.69 \mathrm{~cm}$, last-test $169.84 \pm 21.06 \mathrm{~cm}$, Speed test $(\mathrm{F}=11.024)$; pre-test $2.40 \pm 0.27 \mathrm{sc}, \mathrm{ss}$, last-test $2.10 \pm 0.28 \mathrm{sc}, \mathrm{ss}$, very significant differences has been found at the parameters $\mathrm{p}<0.01$ (Table 3).

When comparisons of the pre -last test results of female judokas' of the control group determined; rapidity test ( $\mathrm{F}=17.044)$; pre-test $4.60 \pm 0.32 \mathrm{sc}, \mathrm{ss}$, last-test $4.12 \pm 0.26 \mathrm{sc}, \mathrm{ss}$, standing long jump $(\mathrm{F}=47.117)$; pre-test $120.17 \pm 11.19 \mathrm{~cm}$, last-test $158.50 \pm 15.78 \mathrm{~cm}$, grip power $(\mathrm{F}=18.339)$; pre-test $29.84 \pm 12.56 \mathrm{sc}, \mathrm{ss}$, last-test $66.07 \pm 26.47 \mathrm{sc}$,ss very significant differences has been found at the parameters $\mathrm{p}<0.01$ (Table 4). When comparisons of the pre -last test results of female judokas' of the control group determined; speed ( $\mathrm{F}=6.625)$; pre-test $2.74 \pm 0.39 \mathrm{sc}, \mathrm{ss}$ and last-test $2.25 \pm 0.53 \mathrm{sc}, \mathrm{ss} \mathrm{p}<0.05$ significance has been found at the level (Table 4 ).

\section{Discussion and Conclusion}

Very Significance differences has been found at the static balance, quickness, hand grip, speed parameters of test results of application group male judokas $\mathrm{p}<0.01$. Significance has been found at the Standing,long jump, ball throwing, coordination parameters (Table 1). Very significance differences has been found at the standing long 
jump, sprint parameters of test results of control group male judokas $\mathrm{p}<0.01$ (Table 1,3 ).

Very significance differences has been found at the static balance,rapidity,standing long jump, coordination,grip power,speed parameters of test results of application group female judokas. $p<0.01$ Significance has been found at the rapidity, standing long jump, grip power parameters of test results of control group female judokas. $p<0.01$ $\mathrm{p}<0.05$ (Table 2,4).

The best physical activity game for kids Participation in regular physical activity (PA) among children is linked to several health outcomes (Bouchard et al., 1994), as well as to the development of social and academic abilities in youth (Trudeau and Shephard, 2008). Physical inactivity is also known to be associated with an increased risk for overweight and obesity (Hill and Melanson, 1999).

When the effect of the traditional games is observed on the skill development of 7-9 years aged male children it has been seen that traditional games are more efficient than the daily activities for The basic motor skill, object control skills and local control skills. So it is convenient to develop motor skills with traditional game programe (Akbari et al. 2009, s. 123-129).

Game actions are important datathat are directly affected by the modifications (Arias et al., 2009a; 2009b; Parlebas, 1999; Williams et al., 2005). In a study on motor development in preschool children; it is examined the relationship between motor skill performance and physical activity.the percentage of time spent has been examined at the mild, moderate, severe physical activity of the children. The children at the severe physical activity spend more time than the mild and moderate groups. The children in the group of locomotor spend less time by sitting than the other group children. Children from low motor skill performance are less active than the motor skilled children. The relationship between motor skill performance and phsycal activity is important for prevent the child's health badly,specially obesity. Clinic doctors are to study with the families to develop children's motor skill and to encourage for activities (Williams et al. 2008, s.1).

Dissertação de Mestrado (2007) has indicated that Judo and jujitsu contributes to the children's motor ddevelopment and he has declared that this Project has to be developed at the special education institutions. Research in sport to achieve the expected success has revealed the need to launch the sports activities during childhood. In this regard, developed countries, attention has focused on childhood sports activities. There are a number of distinctive features of a workout because the child (Ayan and Mülazimoğlu, 2008, s. 113-118).

Considering these studies, the following conclusions and recommendations of the study was increased.

- This study applied the same top-level athletes training to install the development of motor skills can be examined outside the influence.

- Judo training and educational games to install work can be performed comparing the development of motor skills.

- Different training methods of Judo in the contribution to the development of motor skills by using educational games can be analyzed.

- They are in the process of rapid development of children aged 7-12 years in the period of the game in the forms recommended for use in training systems. This process is accelerating the development of basic motor skills training courses organized Judo can be used as educational games

- Judo training methods, motor skill development with educational games to evaluate the effects can be researched.

- Judo educational games, using the education of troubled individuals, these studies can be performed on the effect of the kind of behavior of individuals in society to facilitate compliance.

- Judo examined the effect of educational games on the motor development of

- individuals with disabilities. Judo educational games for preschool children with disabilities in education physiological, psychological and cognitive development in a form that can be used as supportive

- Judo training educational games more fun can be installed on the research done by making changes in hormonal values of athletes.

- Children like to have fun while learning at the same time. This study attempted to establish the children playing games to have fun.This studies in which Learning when playing, taking pleasure motives have been used are can be used to increase the potential of athlete.

- Judo educational games can be suggested to all judo Judo coaches and prepare a case booklet. 
- Judo promotional activities, programs, primary education can be used on students.It can be said to contrubite to the increase of the athlete number.

\section{References}

Akbari H, Abdoli B, Shafizadeh M, Khalaji H, Hajihosseini S. \& Ziaee V. (2009). The effect of traditional games in fundamental motor skill development in 7-9 year old boys, Iranian Journal of Pediatrics, 19 (2), 123-129.

Arias, J.L., Argudo, F.M. and Alonso, J.I. (2009a). Effect of the threepoint line change on the game dynamics in girls' minibasketball. Research Quarterly for Exercise and Sport, 80(3), 502-509.

Arias, J.L., Argudo, F.M. and Alonso, J.I. (2009b). An objective method for analyzing two three-point shapes in mini-basketball. Revista Internacional de Medicina y Ciencias de la Actividad Física yel Deporte 9(36), 349-365. (In Spanish: English abstract).

Ataman, A. (2004). Gelişim ve Öğrenme. Gündüz Eğitim ve Yayıncılık: Ankara, 3.Baskı, s.18.

Ayan V, \& Mülazimoğlu O. (2009). Sporda Yetenek Seçimi ve Sporda Yönlendirmede 8-10 Yaş Grubu Erkek Çocuklarının Fiziksel Özelliklerinin ve Bazı Performans Profillerinin İncelenmesi (Ankara Örneği). F.Ü.Săg. Bil.Tup Derg, 2009: 23(3): s.113-118.

Bayazıt, B. (2006). Eğitilebilir Zihinsel Engelli Eğlenceli Atletizim Antrenmanı Programının Psikomotor Özelliklere Etkisi, K.Ü. Sağlık Bilimleri Enstitüsü, Doktora Tezi, Kocaeli, (Danışman Yrd. Doç. Dr. B Meriç), s.78-80.

Bompa, T.O. (2007). Antrenman Kuramı ve Yöntemi 'Dönemleme'. Spor Yayınevi: Ankara, s.14-294.

Bouchard, C., Shephard, R. and Stephens, T. (1994). The consensus Statement. In: Exercise, Fitness and Health: A Consensus of Current Knowledge. Ed: Stephens, C.B.R.S.T. Champaign. IL, Human Kinetics.

Brousse, M., Matsumoto, D. (1999). Judo A Sport and A Way of Life. The International Judo Federation: s.7-10.

Demiral, Ş. (2007). Bayan Judocularda Yetenek Seçimi, M.Ü. Sağlık Bilimleri Enstitüsü, Yüksek Lisan Tezi, İstanbul, (Danışman: Yrd. Doç. Dr. A Demir), s.14-15.

Gençlik ve Spor Genel Müdürlüğü Spor Eğitim Dairesi Başkanlığı. (2005). Olimpiyatlar için Sporda Yetenek Seçimi ve Spora Yönlendirme Projesi, Ankara, 2005, yayın-no: 170, s.52-61.

Hill, J.O. and Melanson, E.L. (1999). Overview of the determinants of overweight and obesity: current evidence and research issues. Medicine and Science in Sports and Exercise, 31, S515-521.

Hu1-Tzu, W. (2003). The Effects of a Creative Movement Program on Motor Creativity and Gross Motor Skills of Preschool Children, Doctor of Education, The University of South Dakota, UMI Number: 3085448, USA, 2003, s:1.

Kızılyaprak, A. (2010). Judo Federasyonu Büyük ve Genç Bayanlar Teknik Direktörü.

Matsumoto, D. (2004). The Psychological and Behavioral Effects The USJF Development Committee of Judo, United States Judo Federation, s.1.

Mengütay, S. (2006). Çocuklarda Hareket Gelişimi ve Spor. Morpa Kültür Yayınları Ltd. Ş: İstanbul, s.114.

Mestrado, D. (2007). Judo E Jıu-Jıtsu E O Desenvolvımento Integral De Crıanças, Emserıes Escolares Inıcıaıs, São Leopoldo, s.1

Özer S, K Özer. (2000). Çocuklarda Motor Gelişimi. Kazancı Kitap A.Ş: İstanbul, s.187-180-181-166-186.

Parlebas, P. (1999). Games, sport, and society. Dictionary of motor praxiology. INSEP-Publications, Paris, France.

Trudeau, F. and Shephard, R.J. (2008). Physical education, school physical activity, school sports and academic performance. International Journal of Behavioral Nutrition and Physical Activity, 5:10. doi:10.1186/1479-5868-5-10, http://dx.doi.org/10.1186/1479-5868-5-10

Williams HG, A Karin, Feiffer P, O.Neill J.R, Dowda M., McIver K.L., Brown WH.and Pate RR. (2008). Motor Skill Performance and Physical Activity in Preschool Children, (Published online) 3, April, 1.

Williams, J., Hughes, M. and O'Donoghue, P. (2005). The effect of rule changes on match and ball in play time in rugby union. International Journal of Performance Analysis in Sport, 5(3), 1-11. 


\section{Note}

Note 1. Judoka; person that receives Judo training

Table 1. Application group male judokas Pre-Last Test Results

\begin{tabular}{|c|l|l|l|l|l|l|}
\hline \multirow{2}{*}{ PARAMETERS } & \multicolumn{2}{|c|}{ Pre-Test n=18 } & \multicolumn{2}{c|}{ Last-Test n=18 } & \multicolumn{2}{c|}{ ANOVA } \\
\cline { 2 - 7 } & \multicolumn{1}{|c|}{$\mathbf{X}$} & \multicolumn{1}{|c|}{$\mathbf{S S}$} & $\mathbf{X}$ & \multicolumn{1}{c|}{$\mathbf{\text { SS }}$} & \multicolumn{1}{c|}{ P } \\
\hline Static Balance (mn.sc,ss) & $01: 27.68$ & $01: 23.21$ & $03: 14.79$ & $02: 27.09$ & 7.230 & $.011 * *$ \\
\hline $\begin{array}{c}\text { Dynamic Balance (the number of } \\
\text { repeat) }\end{array}$ & 6.39 & 4.67 & 8.22 & 4.58 & 1.414 & .243 \\
\hline Rapidity (sc,ss) & 4.83 & .49 & 4.22 & .53 & 13.222 & $.001 * *$ \\
\hline Standing long jump (cm) & 147.33 & 15.44 & 164.00 & 17.85 & 8.976 & $.005^{*}$ \\
\hline Ball throw (cm) & 377.33 & 73.76 & 438.50 & 96.90 & 4.541 & $.040^{*}$ \\
\hline Coordination (sc,ss) & 15.60 & 2.23 & 13.90 & 1.45 & 7.392 & $.010^{*}$ \\
\hline Grip Power (sc,ss) & 71.98 & 34.77 & 110.90 & 36.64 & 10.689 & $.002^{* *}$ \\
\hline Speed (sc,ss) & 2.48 & .16 & 2.25 & .17 & 16.637 & $.000^{* *}$ \\
\hline
\end{tabular}

$* * \mathrm{p}<0.01$ ve $* \mathrm{p}<0.05$

Table 2. Application group female judokas Pre-Last Test Results

\begin{tabular}{|c|l|l|l|l|l|l|}
\hline \multirow{2}{*}{ PARAMETERS } & \multicolumn{2}{|c|}{ Pre-Test n=20 } & \multicolumn{1}{c|}{ Last-Test n=20 } & \multicolumn{2}{c|}{ ANOVA } \\
\cline { 2 - 7 } & \multicolumn{1}{|c|}{$\mathbf{X}$} & \multicolumn{1}{c|}{ SS } & \multicolumn{1}{c|}{ X } & \multicolumn{1}{c|}{ SS } & \multicolumn{1}{c|}{ F } & \multicolumn{1}{c|}{ P } \\
\hline Static Balance(min.sc,ss) & p2:42.01 & $02: 21.490$ & $05: 57.92$ & $03: 47.703$ & 10.681 & $.002^{* *}$ \\
\hline $\begin{array}{c}\text { Dynamic Balance (Number of } \\
\text { repeat) }\end{array}$ & 8.00 & 5.51 & 10.40 & 5.91 & 1.767 & .192 \\
\hline Rapidity (sc,ss) & 4.89 & .42 & 3.97 & .49 & 40.468 & $.000^{* *}$ \\
\hline Standing long jump (cm) & 146.50 & 19.00 & 165.10 & 19.02 & 9.573 & $.004^{* *}$ \\
\hline Ball throw (cm) & 383.80 & 125.09 & 443.60 & 116.91 & 2.440 & .127 \\
\hline Coordination (sc,ss) & 16.38 & 1.14 & 14.17 & 2.53 & 12.608 & $.001 * *$ \\
\hline Grip Power (sc,ss) & 68.05 & 30.84 & 113.02 & 35.91 & 18.049 & $.000^{* *}$ \\
\hline Speed (sc,ss) & 2.54 & .19 & 2.24 & .19 & 26.246 & $.000^{* *}$ \\
\hline
\end{tabular}


Table 3. Control group male judokas Pre- Last Test Results

\begin{tabular}{|c|c|c|c|c|c|c|}
\hline \multirow{2}{*}{ PARAMETERS } & \multicolumn{2}{|c|}{ Pre-Test $\mathbf{n = 1 9}$} & \multicolumn{2}{c|}{ Last-Test $\mathbf{n = 1 9}$} & \multicolumn{2}{c|}{ ANOVA } \\
\cline { 2 - 7 } & $\mathbf{X}$ & $\mathbf{S S}$ & $\mathbf{X}$ & $\mathbf{S S}$ & $\mathbf{F}$ & $\mathbf{P}$ \\
\hline Static Balance(min.sc,ss) & $01: 47.56$ & $01: 37.063$ & $02: 07.03$ & $01: 42.678$ & .361 & .552 \\
\hline Dynamic Balance (Number of repeat) & 3.84 & 2.24 & 4.63 & 2.27 & 1.165 & .288 \\
\hline Rapidity (sc,ss) & 4.51 & .64 & 4.24 & .67 & 1.512 & .227 \\
\hline Standing long jump (cm) & 138.53 & 21.69 & 169.84 & 21.06 & 20.389 & $.000^{* *}$ \\
\hline Ball throw (cm) & 422.95 & 78.86 & 498.63 & 98.98 & 6.795 & .013 \\
\hline Coordination (sc,ss) & 14.32 & 1.65 & 13.94 & 1.57 & .519 & .476 \\
\hline Grip Power (sc,ss) & 45.41 & 25.17 & 64.54 & 39.31 & 3.190 & .082 \\
\hline Speed (sc,ss) & 2.40 & .27 & 2.10 & .28 & 11.024 & $.002^{* *}$ \\
\hline
\end{tabular}

$* * \mathrm{p}<0.01$

Table 4. Control group female judokas Pre-Last Test Results

\begin{tabular}{|c|l|l|l|l|l|c|}
\hline \multirow{2}{*}{ PARAMETERS } & \multicolumn{2}{l}{ Pre-Test n=12 } & \multicolumn{2}{l|}{ Last-Test n=12 } & \multicolumn{2}{l|}{ ANOVA } \\
\cline { 2 - 8 } & $\mathbf{X}$ & $\mathbf{S S}$ & $\mathbf{X}$ & $\mathbf{S S}$ & $\mathbf{F}$ & $\mathbf{P}$ \\
\hline Static Balance (min.sc,ss) & $02: 50.43$ & $02: 49.330$ & $03: 22.50$ & $02: 46.417$ & 219 & 644 \\
\hline $\begin{array}{c}\text { Dynamic Balance (Number of } \\
\text { repeat) }\end{array}$ & 6.25 & 3.47 & 7.08 & 3.15 & 380 & 544 \\
\hline Rapidity (sc,ss) & 4.60 & .32 & 4.12 & .26 & 17.044 & $.000^{* *}$ \\
\hline Standing long jump (cm) & 120.17 & 11.19 & 158.50 & 15.78 & 47.117 & $.000^{* *}$ \\
\hline Ball throw (cm) & 340.25 & 101.76 & 423.25 & 117.00 & 3.438 & .077 \\
\hline Coordination (sc,ss) & 14.75 & 1.49 & 14.37 & 1.31 & .446 & .511 \\
\hline Grip Power (sc,ss) & 29.84 & 12.56 & 66.07 & 26.47 & 18.339 & $.000^{* *}$ \\
\hline Speed (sc,ss) & 2.74 & .39 & 2.25 & .53 & 6.625 & $.017^{*}$ \\
\hline
\end{tabular}

$* * \mathrm{p}<0.01$ ve $* \mathrm{p}<0.05$ 